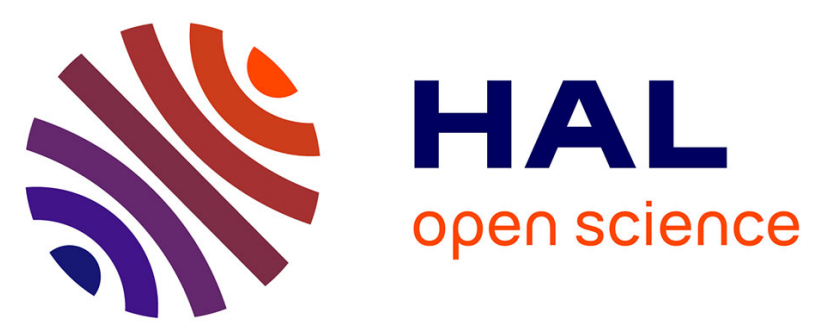

\title{
Measuring Ilocano's catholic youth's attitude toward the catholic church and their behavioural intention to help the social action of the catholic church in the Philippines context
}

\author{
Damianus Abun, Theogenia Magallanes, Jean Rachel Barroga, Mary Joy \\ Encarnacion, Sylvia Lalain Foronda
}

\section{To cite this version:}

Damianus Abun, Theogenia Magallanes, Jean Rachel Barroga, Mary Joy Encarnacion, Sylvia Lalain Foronda. Measuring Ilocano's catholic youth's attitude toward the catholic church and their behavioural intention to help the social action of the catholic church in the Philippines context. International Journal of Business, Management and Social Research, 2020, Measuring Ilocano's catholic youth's attitude toward the catholic church and their behavioural intention to help the social action of the catholic church in the Philippines context, 8 (2), pp.473-488. 10.18801/ijbmsr.080220.49 . hal-02567811

\section{HAL Id: hal-02567811 \\ https://hal.science/hal-02567811}

Submitted on 8 May 2020

HAL is a multi-disciplinary open access archive for the deposit and dissemination of scientific research documents, whether they are published or not. The documents may come from teaching and research institutions in France or abroad, or from public or private research centers.
L'archive ouverte pluridisciplinaire HAL, est destinée au dépôt et à la diffusion de documents scientifiques de niveau recherche, publiés ou non, émanant des établissements d'enseignement et de recherche français ou étrangers, des laboratoires publics ou privés.

\section{(ㄷ)(1) $\$$}

Distributed under a Creative Commons Attribution - NonCommerciall 4.0 International 


\title{
Measuring Ilocano's catholic youth's attitude toward the catholic church and their behavioural intention to help the social action of the catholic church in the Philippines context
}

\author{
Damianus Abun ${ }^{1,2}$, Theogenia Magallanes ${ }^{2}$, Jean Rachel Barroga ${ }^{1}$, Mary Joy \\ Encarnacion $^{1}$ and Sylvia Lalain Foronda ${ }^{3}$
}

\author{
Divine Word College of Vigan \\ ${ }^{2}$ St. Benedict College of Northern Luzon \\ ${ }^{3}$ Divine Word College of Laoag, Philippines.
}

$\square$ Corresponding author: nusabun@gmail.com (Abun, D.).

Article Received: 04.02.2020; Revised: 07.04.2020 and Published online: 25 April 2020.

\begin{abstract}
The study wanted to determine the correlation between the cognitive and affective attitude of the Catholic youth toward the Catholic Church and their behavioral intention to help the Social action of the Church in the future. To support the study, related literature and studies were reviewed. The study used a descriptive correlational research design. 400 youth were taken as respondents of the study. To gather the data, validated questionnaires were used, and the data were interpreted and analyzed using statistical tools such as Pearson $r$ and Weighted mean. The study found that Catholic youth have a very high positive cognitive and affective attitude toward the Catholic Church and their behavioral intention to help the Church is also very high. Further, there is a correlation between the Catholic Youth's cognitive and affective attitude and the behavioral intention to help the social action of the Catholic Church in the future.
\end{abstract}

Key Words: Catholic Youth's attitude, Youth's behavioral intention, Social action, human attitude, and human behavior.

Cite Article: Abun, D., Magallanes, T., Barroga, J. R., Encarnacion, M. J. and Foronda, S. L. (2020). Measuring Ilocano's catholic youth's attitude toward the catholic church and their behavioural intention to help the social action of the catholic church in the Philippines context. International Journal of Business, Management and Social Research, 08(02), 473-488. Crossref: https://doi.org/10.18801/ijbmsr.080220.49.

Article distributed under terms of a Creative Common Attribution 4.0 International License.

\section{Introduction}

The role of the Catholic Church cannot be undermined in the history of western civilization. We may argue that the history of Christianity is also the history and the formation and the development of western society. The Catholic Church ever since has been contributing to its development through its services. We can identify several of its services such as education and medical care. In the west, it has opened first Catholic Universities, Colleges and even basic education to educate people (Blainey, 2011). 
Through education and its social teaching, the Church has inculcated Christian values to form the moral foundation of western society (Brooke and Numbers, 2011). Through education and its teaching, the Church has opened the mind of its followers to respect the sanctity of human life (Lecky, 1920; Gushee, 2014), to respect the right of women and children (Keller, 2008), respect human rights which was originated from the teaching St. Thomas Aquinas (Gonenc, 2002; Kim and Kaul, 2015; Goyette et al. 2004). Through the Western Missionaries who are assigned in different parts of the world, including Asia and Africa, education, social services and social teaching of the Catholic Church have spread throughout the world. Now, everywhere in the world, education, medical care has been part of its social ministry. Many can see that there are many hospitals that are run by Catholic Institutions.

Ever since the work of the Catholic Church is not limited to liturgical services or sacramental services but it involves social actions that are based on the teaching of Jesus Christ. With the presence of "Populorum Progressio" of John Paul VI (1967), the Catholic Church had institutionalized the Catholic Social Action. Populorum Progressio was inspired by the Second Vatican Council, which moves the Bishops to approve social action initiatives that were by individual priests and lay partners (Sadowski, 2017). The office addresses poverty, social justice, peace, and even human rights concerns. Even before the Populorum Progressio came out, the Catholic Church has been involved in human development efforts. Thus, one cannot undermine the role of the Catholic Church in civilizing the society ever since way before the Second Vatican Council through education and technology, its role in changing the ways how politics should be and how business should be carried out and its influence on ethical theories around the globe.

Thus, based on what we have mentioned above, we have a very clear view of the role of the Catholic Church in human society. We have the idea that the Catholic Church is playing a very important role in human society in transforming society into a civilized society that is based on Christian values. But one can have such view if he/she knows the history of the Catholic Church in civilizing the society and its particular contribution in social development and we can only get this view from the old folks who are still alive and product of the history. Definitely, we may not get this view or concept from the millennials or the young generation. Detach from history and experience, one can have a different view of certain objects or subjects or events. It is on this concern; the researcher would like to find out the attitudes of the Illocano's Catholic youth in Ilocos Region on the Catholic Church and if their attitude toward the Catholic Church affects their intention to help the social action program of the Catholic Church.

This study is based on the concept of Ajzen (1993) and Allport (1968) that attitude is a key predictor of human behavior. The concept has been carried out by different researchers to find out if the attitude affects behavior. The result of previous studies has been mixed. Some findings confirm the theory and others do not confirm the theory. There have been discussions on the reason why there are conflicting findings. Context can play a mediating factor in the behavior. The study would like to understand the attitude of the Illocano's Catholic Youth in Ilocos Region's context particularly among the Catholic youth who are still studying at catholic colleges. This is to determine if the Ilocano Youth have the idea or feeling toward the Catholic Church and if their ideas or feelings toward Catholic Church affect their behavior toward their positive contribution to the work of the Catholic Church.

The study is divided into five parts. The first part is the introduction which discusses the rationale and the objective of the study. The second part is the review of the related literature and studies related to the concept of human attitude, human behavior, the relationship between human attitude and human behavior, attitude toward the Catholic Church, the Catholic Church Social Action and the conceptual framework of the study. The third part is the research methodology that discusses the research design, population, research instruments, data gathering procedures, the locale of the study and statistical treatment of data. The fourth part is empirical data and analysis. The fifth part is about the result and discussion which discusses the result of the study, implication, and conclusion of the study.

\section{Review of Literature}

To understand the topic that we are discussing, we use the concept of social psychology to discuss attitude and human behavior. The researcher has used the same concept in his previous studies on attitude toward research and behavioral intention to conduct research, and also an attitude toward higher education and academic engagement of students. We adopt the same concepts of attitudes and 
behavior in the current study. We do not problematize the domain of social psychology, but we borrow the concepts and apply them in our current study.

\section{Attitude is about the knowledge, feeling, and behavior toward a certain object}

A simple definition of attitude is like Ajzen's (1993) definition, that it is an individual view or disposition toward certain things or objects. According to Ajzen (1993), there are many definitions about attitude but they have a common understanding that though attitudes are hidden but it can be evaluated or can be measured (Bem, 1970; Edwards, 1957; Fishbein and Ajzen, 1975). They can be measured through the reaction or statement of the person toward the object he/she is encountering. The reaction or statement of the person may reflect his/her knowledge and feelings toward the object and therefore the measurement must reflect the knowledge (cognitive), feeling (affective) and the behavior of the person toward the object (Allport, 1954; Hilgard, 1980; Rosenberg and Hovland, 1960). On one hand, the knowledge (cognitive) component of the attitude reflects what the person knows about the object. While feeling component is about how the person feels toward the object. Whereas behavioral component or conative refers to behavioral reaction toward the object. According to Ajzen (1993) and Allport, the behavioral reaction is the product of knowledge and feeling toward the object. The behavioral reaction may include the plans or intentions of what to do with the object. Thus, according to Allport (1968) attitude is a key to analyze or to understand the behavior of the person toward a certain object.

\section{An anthropological view of the origin of attitude is culture}

Human beings are born in a certain place and are raised in a certain place with its unique characteristics. Though Aljzen (1993) argued that attitude can be a result of exposures such watching television programs or through experience but Abun and Racoma (2017) in his argument about the root cause of environmental problems pointed out that environmental problems are caused destructive behavior and such destructive behaviors are caused by their attitude and such attitude is formed by culture. Along with such an argument, Abun and Racoma (2017) recommended that solving the environmental problem is to review the culture or change of the culture.

Abun's argument was reemphasizing the ideas of anthropologists such as Donald (2002), Hofstede as cited by Brown (1995). Donald (2002) have argued that culture has formed the mind of the person since childhood and is playing an important role in brain functioning and even brain structure. He further explained that cultures have effectively wired up the functional subsystem in the brain that would not otherwise exist. One could not argue further to deny the role of culture in one's views toward a certain object as Abun et. al. (2018) pointed out further that the mind or perception and the behavior reflect the culture of the person. While Donald's (2002)view is the same with Hofstede's view as cited by Brown (1995), which emphasized the role of culture in the formation of the human brain and distinguishes the members of one human group from those of another. Hofstede explained that culture form people in the way how they think or view things. To elaborate further, Amstrong (1996) contends that culture also forms the ethical perception of people. In this case, attitude toward a certain object can be different from one person to another if they are raised in the different contexts of society.

\section{Behavioral Psychologist view of the root cause of human behavior is the mind}

Controversies surrounding the origin of human behavior continues. According to a behavioral psychologist, William James as cited by Lawler (2006) that human behavior is not shaped by experience, practice or culture but it is shaped by the brain or the mind. He makes his point that minds make a difference between animals and human beings. Though James accepts that humans and animals have instincts but what makes humans behave differently is because of their reasons or mind. He continues to make his point that though both have instincts but the way how they react toward certain objects different. Human beings are not reacting automatically as animals do. Human beings use their mind or reason on how to react or behave. It is the role of the reason that animals do not have.

In support of the argument of William James as cited by Lawler, Ridley (2003) brings us to his account of the root cause of human behavior with his intriguing question: "what makes us who we are?" This question calls our attention again to the main argument of William James about the difference between human beings and animals. What makes us different between human beings and animals is the mind or reason. It is the essence of human beings and makes him a human being. This argument brings us to the theory of planned behavior of Ajzen (1985); Ajzen (1987); Ajzen and Madden (1986). The theory of 
planned behavior (TPB) explains the relationship between reason and action or between attitude and behavior. Reasoned Action Theory (RAT) argues that humans are not acting instinctively but they behave based on pre-existing reason. They also do not behave automatically but based on the expected outcome of the behavior as a result of performing such behavior (Fishbein and Ajzen, 1975; Ajzen and Fishbein, 1980). In other words, the Theory of Planned Behavior argues that people behave in certain ways base on what they intend to achieve by performing such behavior. According to Ajzen (1993), there are three independent determinants of intention. The first determinant is the attitude toward the behavior whether the behavior in question is favorable or not favorable. The second determinant is a social factor or subjective norms in which the person will evaluate the behavior if it is socially acceptable or not. The third determinant is the novel antecedence of intention if performing such behavior easy or difficult and such evaluation can be based on the experience of performing a similar behavior. According to Ajzen (1993), that "the more favorable the attitude and subjective norms concerning behavior, and the greater the perceived behavioral control, the stronger should be an individual's intention to perform the behavior under consideration" In short, the theory of planned behavior argues that the stronger people's intention to perform a certain behavior, or the stronger people's intention to achieve their behavioral goals the more likely they engage in such behavior.

\section{Conflict of findings over the influence of attitude toward behavior}

It has been accepted that attitude is beliefs, emotions, and behaviors toward a certain object or a thing (Banaji and Heiphetz, 2010) and they are learned. It means that the belief, emotions, and behavior toward a certain object or thing are not isolated from exposure or experience. It is a result of experience, upbringing, education, and social interactions. Therefore, it is not independent of the environment and therefore it is dynamic which means that attitude can be changed (Cherry, 2019).

The idea of attitude affecting human behavior had been challenged by other researchers. Early researchers had the common findings that attitude influences the behavior. The early studies used the idea of the social psychologist who argued that a key to understanding human behavior is the attitude (Thomas and Znaniecki, 1918; Watson, 1925). Studies were built on this theory for quite some time until the time other researchers disapprove of the theory. Researchers challenged the findings through field studies, and they found that there is no correlation or little correlation between attitude and human behavior. We can take the example of the study of Corey (1937), Freeman and Ataoev (1960) as cited by Ajzen (1993). They conducted a study on college students' attitudes toward cheating at the beginning of the semester and cheating behavior (Ajzen, 1993). The study found no correlation between students' attitude toward cheating and actual cheating behavior. Later studies also supported the finding. Dean (1958) studied the attitude toward labor unions and participation in labor union meetings, the study found that there is no correlation between attitude toward labor union and actual participation in labor union meetings. Wicker (1969), Wicker and Pomazal, (1971) also conducted a study on the attitude toward participating in a subject in social psychology and actual participation in a social psychology class. Their studies found no correlation between attitude toward participating in a subject and actual class participation.

The finding of later studies particularly the study of Wicker (1969), Wicker and Pomasal (1971) put the original finding into controversy. Their studies put the theory of social psychologist in jeopardy. As a result, many researchers questioned the importance of studying the relationship between attitude and behavior. Since then, the direction of the study changed, instead of studying the relationship between attitude and behavior, the researchers were encouraged o study the relationship between social context and norms as determinant factors in predicting human (De Fleur and Westie, 1958; Deutscher, 1969). However, those who been influenced by the original comfortable development, particularly Ajzen and Fishbein (1977); Ajzen and Fishbein (2000). Ajzen still maintained that attitude is still key to predict the behavior as proposed by social psychologist Allport (1968). Ajzen defended the idea of Allport (1968) who argued that attitude is "the most distinctive and indispensable concept in contemporary American social psychology and as a key predictor to human behavior" (p. 59). Ajzen argued that those conflicting findings should blame the theory of attitude as a key predictor of behavior, but it may be caused by other factors such as "response biases, the multidimensionality of attitudes, and moderating variables". According to Ajzen, during the answer of questionnaires, the respondents tend to choose the socially desirable answer. Further, he argued that most attitude measurement techniques resulted in a single score representing the respondent's overall positive or negative reaction to the attitude object which does not do justice to the complexity of attitude construct (Allport, 1935). Rosenberg and Hovland 
(1960) support the argument by pointing out that a "single construct is against attitude as a multidimensional construct which includes cognition, affective and conation component". Lastly, the inconsistencies can be caused by moderating variables. The attitude-behavior is assumed to be moderated by factors such as "self-awareness, self-efficacy, self-monitoring, experience, self-confidence, even feeling and lack of information or knowledge".

The latest studies seem to confirm the theory of early social psychologists and the finding of Ajzen. Take examples from Abun and Racoma (2017); Abun et. al. (2018) and Fitzsimmons and Douglas (2005). Theis studies support the theory of the correlation between attitude and behavior. For example, Abun and Racoma (2017) studies the correlation between environmental attitude and environmental behavior of students and the study found a correlation between the two variables. Abun et. al. (2018) also conducted a study measuring the relationship between entrepreneurial attitude and entrepreneurial behavioral intention to establish a business in the future. The study found a correlation. The study of Fitzsimmons and Douglas (2005) also found that entrepreneurial attitudes are a significant factor in predicting behavioral intention to conduct business in the future.

\section{Attitude toward the catholic church}

The main question here is: does the attitude of the Catholic Youth now toward the Catholic Church is still the same as the early days? However, before we answer that question, once again we need to understand the concept of attitude so that we know what we mean when we talk about the attitude toward the Church. Social psychology defines attitude as the value that a person places on something or the object of the attitude. The object of attitude can be a person, a group, an institution or events (Richardson, n.d). Or in psychology, it can be defined as a set of emotions, beliefs, and behaviors toward a particular object or subject or institution (Cherry, 2019). The object of attitude here can be the Catholic Church. In other words, attitude toward the Catholic Church can mean the reactions or responses of the Catholic youth toward the Catholic Church, be it positive or negative. Therefore, the concern in the investigation is the knowledge and feelings of the Catholic youth toward the Catholic Church and their behavioral intention to help the Church. The focus of the investigation then is about youth's cognitive, affective and conative response or reaction toward the Church and these dimensions are important dimensions in measuring the attitude and the behavior as pointed out by Allport, (1954); Hilgard (1980), and Rosenberg and Hovland, (1960). Cognitive response refers to the ideas or thoughts of the Catholic youth toward the Catholic Church. It is about their thoughts or perceptions ofthe Catholic Church. The affective attitude is about the emotional reactions of the youth toward the Catholic Church. While the conative or behavioral response is about the intention of the youth to help the social action of the Church in the future. It is about his/her plan on what to do as the realization of his/her attitude.

\section{Catholic church social action}

The Second Vatican Council had changed the mind of the Catholic Church's leadership on how it sees itself, that it is not anymore separated from the world, but it is part of the world. As part of the world, it cannot ignore the concern of the world, but it has to participate in solving human problems issues. It had opened its windows to the outside world (Baldelomar, 2010). Since then the Catholic Church started institutionalizing its social action that was originally done by individual priests and lay partners. It was the beginning that the Catholic Church stressed social justice strongly. As Duncan (2006, para. 1) argued the Church's concern and participation in the social issues are originated in the belief that "God identifies intensely with oppressed and the distressed" of the earth. Such concern must stand out as a marker of Catholic identity (Baldelomar, 2010). In its line of social concern, the Church has identified seven themes in its social teaching such as life and dignity of human person, call to family, community and participation, rights and responsibilities, option for the poor and vulnerable, The dignity of works and the rights of workers, solidarity, and cares for God's creation (United States Conference of Catholic Bishops, 1998).

In its social teaching, the Church discusses matters on human dignity and the common good in society. It addresses issues of oppression, the role of the state, social organization, social justice, and issues on wealth distribution. These concerns are actually inspired by the Rerum Novarum, the encyclical letter of Pope Leo XIII in 1891 that discussed economic distribution. The Rerum Novarum is also a result of reflection over the writings of theologians such as Thomas Aquinas and Augustine of Hippo which is also inspired by the Bible (Martin, 2004). This document was also developed by John Paul XXIII with his 
Mater et Magistra with its subtitle, "Christianity and Social Progress". This document expanded the social doctrine to include international relations particularly on the relations between poor and rich countries in which the rich countries have obligations toward the poor countries. Later on, such a document was expanded in the Pacem in Terris. In such a document, the Pope emphasized world peace and such world peace is the rights and responsibilities of individuals, social groups and states and Pope urged Catholics to apply social teachings (Hittinger, 2013; Sorondo, 2013).

Catholic social teaching has inspired Churches and religious communities to establishes social action offices to carry out programs that address social issues such as poverty, human rights, discrimination, environmental problems, and many more social issues. However, Churches and religious communities are often facing problems related to resources, not only human resources but mostly financial resources to carry out the programs. Pope John Paul XXIII has anticipated this problem and thus he invited all Catholics and even other religions to participate in solving these social issues.

\section{Attitude toward the catholic church has changed over time}

The attitude of the Catholics toward the Catholic Church has changed from the past centuries and the present. It is recognized that the earlier Church had played an important role in the civilization of society and established the moral foundation of civilized society and such role had also influenced the attitude of people toward the Church. In the early days, the Church was considered a powerful institution. However, early days' attitudes do not stay forever, it had changed because of experience encountered in real life as pointed out by Cherry (2019). It is the nature of attitude because it is not independent of the environment or daily experience. Since the environment and experiences are dynamics, therefore, attitude also changes. Such changes of attitude do happen in human attitude toward the Church. The environment and the experiences of early members of the Church are different from the environment and experience of current members of the Church. According to the data from the World Values Survey (WVS) conducted by the Institute for Social Research (ISR) as cited by Swanbrow (2005), that the attitude of Roman Catholics in America, Spain, and Mexico continues to change. The study showed that though they are still identified with the Church, such identification is not reflected in their attitude. For example, the survey pointed out that though the Catholic Church holds that divorce is never justifiable but the position of people toward the Church's position is declining. The decline is followed by a decline in Church attendance. This was also recognized by the study of Rymarz and Graham (2006) on the Australian Catholic youth. Their study pointed out that religious communities have a hard time to pass on their beliefs for future generations. The study found that most adolescents have a weak familial pattern of Church attendance and predicted a likely decrease in their future participation. The study pointed out that many core Catholic adolescents are likely to become less involved in Church life in the future.

The above findings indicate that the attitude of people toward the church has changed and since their attitude toward the Church has changed, consequently, their behavior to commit themselves to carry out the teaching of the Church and their attendance to Church activities also change. Such changes did not only happen in America, Spain, and Mexico, it also happens in other countries. The CBCP-Episcopal Commission on Youth (2003) as cited by Sarmiento (2016) commissioned the National Filipino catholic Youth survey in 2002, to gather information about the Filipino youth. The survey found that many young Catholic Filipino either seldom practice their faith or do not practice it at all. They seldom pray and never participate in Church activities. It is alarming. However, this pattern has not established itself as a prevalent attitude. At least, in the Philippines context, the Catholic youth's attitude toward the Catholic Church seems to be reversed because the last survey, in 2013, the same CBCP-Episcopal Commission on Youth (2013) conducted similar survey and the survey found that majority of Filipino youth confirmed their belief on the basic doctrine of the Catholic Church and majority of them confirm their participation in the Church activities. Unfortunately, the causes of such reversal were not investigated.

In relation to their views or attitude toward Catholic Church, CBCP-Episcopal Commission on Youth and the Catholic Educational Association of the Philippines (2014) in collaboration with the 18 Universities and Colleges Nationwide conduct a survey on the religiosity of the catholic youth of the Philippines. One of the questions was about the importance of religion in their life. The survey revealed that 89.5 percent of respondents consider religion to be very important, and 8.7 percent considered religion to be somewhat important and only 0.4 percent consider religion to be not important at all. In short, it is around 98.4 percent consider religion as important and only 1.4 percent of youth thought that religion 
is not very important, or a total of 1.8 percent do not consider religion to be important. Following such an attitude is their religiosity. The same survey pointed out that a total of 86.1 percent considered themselves to be religious in which 38.5 percent considered themselves as very religious and 47.6 percent considered themselves to be somewhat religious. It was only a total of 14 percent considered themselves to be not religious. When the participants were asked about their feeling toward religion, they expressed positive emotions, or they feel proud to be Catholic. Catholic religion provides a sense of joy and comfort.

\section{Conceptual Framework Independent Variables}

\section{Dependent Variables}

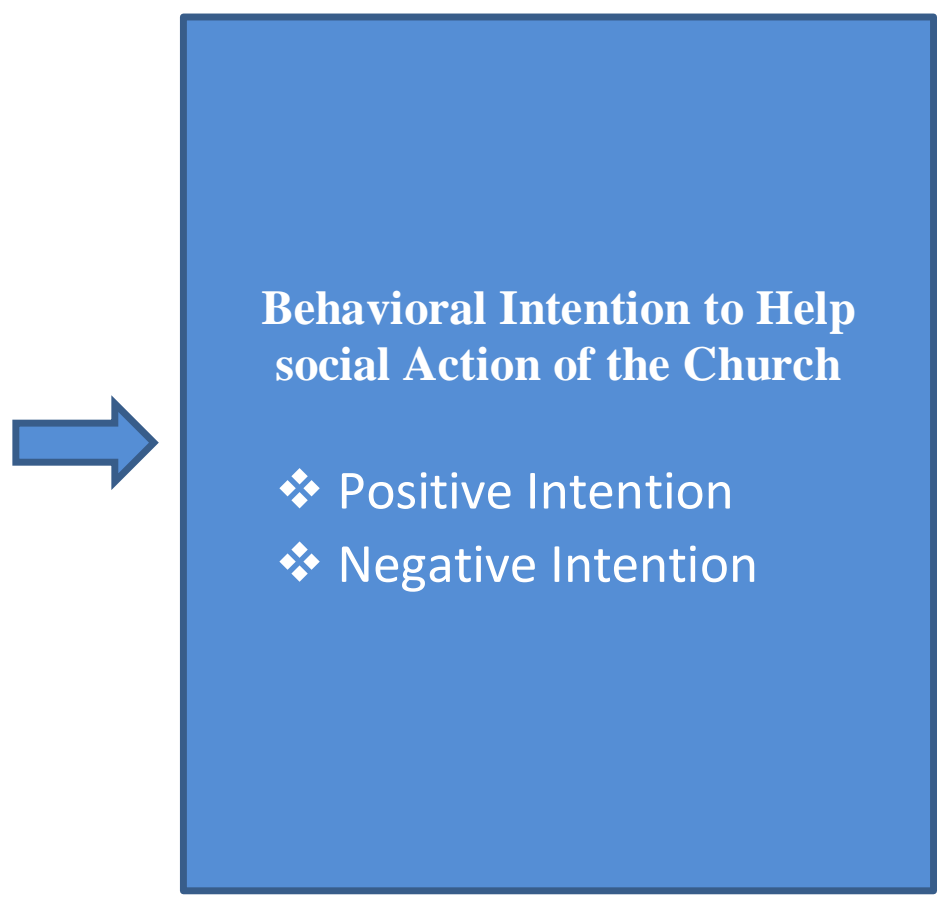

Figure 01. The conceptual framework reflects the relationship between the cognitive and affective attitude toward the Catholic Church and behavioral intention to help the social action of the Catholic Church.

\section{Statement of the problems}

The study intends to determine the relationship between the cognitive and affective attitude of Ilocanos' Catholic youth toward the Catholic Church and their behavioral intention to help the social action of the Catholic Church, specifically to answer the following questions:

1. What is the cognitive attitude of Ilocanos' Catholic youth toward the Catholic Church in terms of:
a. Positive Cognition

b. Negative cognition

2. What is the affective attitude of Ilocanos' Catholic youth toward the Catholic Church in terms of:

a. Affection (positive)

b. Disaffection (negative).

3. What is the behavioral intention of the Ilocanos' Catholic youth to help the social action of the Church in terms of:

a. Positive intention

b. Negative intention

4. Is there a relationship between cognitive and affective attitude toward the Catholic Church and behavioral intention to help the social action of the Church?

\section{Assumption}

The study assumes that cognitive and affective attitude affects human behavior and it can be measured. The questionnaires are valid, and the answers of the respondents are reflecting their true attitudes or perceptions. 


\section{Hypothesis}

Ajzen (1985); Ajzen (1987); Ajzen and Madden (1986) have argued that attitudes affect the human behavior and base on this theory, the current study argues that cognitive and affective attitudes of Ilocanos' Catholic youth toward the Catholic Church affect their behavioral intention to help the social action of the Catholic Church.

\section{Scope and delimitation of the study}

The study limits itself to measure the cognitive and affective attitude of the Ilocanos' Catholic youth toward the Catholic Church and their behavioral intention to help the social action of the Church. It will cover the youth who are still studying at the college level and those who are out of school in Ilocos Sur and Ilocos Norte.

\section{Methodology}

The study was carried out through appropriate research methodologies such as research design, data gathering instruments, population, the locale of the study, data gathering procedures and statistical treatment of data.

\section{Research design}

Since the study is quantitative research and therefore it used descriptive correlational research design and aided by inquiry to determine the level of cognitive and affective attitudes of Ilocanos' Catholic youth toward the Catholic Church and behavioral intentions to help the social action of the Catholic Church. The nature of descriptive research is to describe what is found in the data collected through questionnaires and statistical treatment. It is also used to describe profiles, frequency distribution, describe characteristics of people, situation, phenomena or relationship variables. In short, it describes "what is" about the data (Ariola, 2006; Abun et. al. 2019).

In line with the current study, the descriptive correlational method was deployed. The study determines the level of attitude toward the Catholic Church and its correlation with the plan to help the social action of the Church. This was to determine what the dominant attitudes of Catholic youth toward the Catholic Church were and what particular attitudes affect the behavioral intention to help the social action of the Church.

\section{Study location}

The locale of the study was Catholic Colleges in Ilocos Sur and Ilocos Norte.

\section{Population}

The population of the study was composed of selected samples of catholic youth in IlocosSur and Ilocos Norte. The purposive sampling was used, and 400 youth were taken as respondents of the study.

\section{Data gathering instruments}

The study utilized questionnaires that were made by the researcher and validated by the subject matter expert.

\section{Data gathering procedures}

In the process of data gathering, the researcher sent letters to the President of the Colleges, requesting them to allow the researcher to flow his questionnaires in the college. The researcher personally met the Presidents and employees and requested them to answer the questionnaires.

The retrieval of questionnaires was arranged between the President's representative and the researcher with the help of employees and faculty of the college.

\section{Statistical treatment of data}

In consistence with the study as descriptive research, therefore descriptive statistics were used. The weighted mean is used to determine the level of cognitive and affective attitude toward the Catholic Church and behavioral intention to help the social action of the Church and the Pearson $r$ was used to 
measure the correlation of cognitive and affective attitudes toward the Church and the behavioral intention to help the social action of the Church.

The following ranges of values with their descriptive interpretation will be used:

Statistical Range

4.21-5.00

$3.41-4.20$

2.61-3.40

$1.81-2.60$

$1.00-1.80$

\section{Descriptive Interpretation}

Strongly agree

Agree

Somewhat agree

Disagree

Strongly disagree

\author{
Overall Descriptive Rating \\ Very High \\ High \\ Moderate \\ Low/High \\ Very Low/Very High
}

\section{Results: empirical data analysis}

This section presents the empirical data that were gathered through research questionnaires and the analysis is based on the empirical data. The presentation of empirical data and analysis follows the arrangement of the statement of the problem of the study. The study was seeking the answer to the following problems:

Problem 1: What is the cognitive attitude of Ilocanos' Catholic youth toward the Catholic Church in terms of:

a. Positive Cognition

b. Negative cognition

Table 01. Catholic youth's cognitive attitude toward the catholic church

\begin{tabular}{|l|l|l|}
\hline \multicolumn{1}{|c|}{ a. Positive Cognition } & Mean & DR \\
\hline $\begin{array}{l}\text { 1. Catholic Church is important because it lays the moral foundation of } \\
\text { society. }\end{array}$ & 4.55 & SA \\
\hline 2. Catholic Church is important for making me closer to God. & 4.70 & SA \\
\hline 3. Catholic Church makes me a good person. & 4.52 & SA \\
\hline 4. Catholic Church helps a lot of poor people. & 4.17 & A \\
\hline 5. Catholic Church is playing an important role in society. & 4.35 & SA \\
\hline 6. Catholic Church is against social injustices. & 4.10 & A \\
\hline 7. Catholic Church is living the teaching of Christ. & 4.54 & SA \\
\hline 8. Catholic Church is all about prayer and attending Holy Mass. & 4.28 & SA \\
\hline Composite Mean & 4.40 & SA \\
\hline \multicolumn{1}{|c|}{ begative cognition } & & \\
\hline 1. I think the Catholic Church is not important at all. & 1.37 & SDA \\
\hline $\begin{array}{l}\text { 2. I think the teaching of the Catholic Church does not make me closer to } \\
\text { God. }\end{array}$ & 1.44 & SDA \\
\hline 3. I think that the Catholic Church is irrelevant to my life and society. & 1.54 & SDA \\
\hline 4. I do not know much about the Catholic Church. & 1.64 & SDA \\
\hline 5. I know that the Catholic Church does not make me a better person. & 1.46 & SDA \\
\hline Composite Mean & 1.49 & SDA \\
\hline
\end{tabular}

Legend:
4.21-5.00
3.41-4.20
2.61-3.40
1.81-2.60
$1.00-1.80$

Strongly agree

Agree

Somewhat agree

Disagree

Strongly disagree

Very High
High
Moderate
Low/High
Very Low/Very High

Based on the empirical data, it reveals that as a whole, the positive cognitive attitude of youth toward the Catholic Church is 4.40 which is interpreted as "very high" or "strongly agree". Even when the items are taken singly, students strongly agree that Catholic Church is important because it lays moral 
foundation of the society (4.55), for making them closer to God (4.70), for making them a good person (4.52), Catholic Church is playing important role in the society (4.35), Catholic Church is living the teaching of Christ (4.54), and they strongly agree that Catholic Church is all about prayer and attending Holy Mass (4.28). They also agree that the Catholic Church helps a lot of people (4.17) and it against social injustices (4.10).

In terms of their negative cognitive attitude, it shows that as a whole, the youth achieve the composite mean of 1.49 which means that they strongly disagree with the points raised in the survey. Taking it singly, the youth strongly disagree that Catholic Church is not important at all (1.37), the teaching of Catholic Church does not make them closer to God (1.44), Catholic Church is irrelevant to their life and society (1.54), Catholic Church does not make them a better person (1.46) and they strongly disagree that they do not know much about Catholic Church (1.64).

In short, the youth's negative cognitive attitude toward the Catholic Church confirms their positive cognitive attitude toward the Church. In other words, they have a very high positive cognitive attitude toward the Catholic Church and strongly agree about the importance of the Catholic Church in their life and society.

Problem 2: 2. What is the affective attitude of Ilocanos' Catholic youth toward the Catholic Church in terms of:
a. Affection (positive)
b. Disaffection (negative).

Table 02. Catholic youth's affective attitude toward the catholic church

\begin{tabular}{|l|l|l|}
\hline \multicolumn{1}{|l|}{ a. Positive Component } & Mean & DR \\
\hline $\begin{array}{l}\text { 1. I feel the Catholic Church is important in making young people closer } \\
\text { to God. }\end{array}$ & 4.56 & SA \\
\hline 2. Catholic Church is enjoyable. & 4.43 & SA \\
\hline 3. Belong to the Catholic Church makes me proud. & 4.48 & SA \\
\hline 4. Catholic Church makes me feel good. & 4.51 & SA \\
\hline 5. Catholic Church makes me happy. & 4.52 & SA \\
\hline 6. I feel satisfied belonging to the Catholic Church. & 4.50 & SA \\
\hline Composite Mean & 4.50 & SA \\
\hline \multicolumn{1}{|c|}{ b. Negative component } & 1.35 & SDA \\
\hline 1. Catholic Church makes me angry. & 1.40 & SDA \\
\hline 2. Just thinking of the Catholic Church does not make me happy. & 1.41 & SDA \\
\hline 3. Thinking of the Catholic Church makes me upset. & 1.39 & SDA \\
\hline 4. Catholic Church does not make me proud. & 1.38 & SDA \\
\hline 5. Catholic Church is an additional burden to me. & 1.41 & SDA \\
\hline 6. The Catholic church does not make me a free person. & 1.39 & SDA \\
\hline Composite Mean & &
\end{tabular}

Legend:

4.21-5.00

$3.41-4.20$

$2.61-3.40$

$1.81-2.60$

$1.00-1.80$
Strongly agree

Agree

Somewhat agree

Disagree

Strongly disagree
Very High

High

Moderate

Low/High

Very Low/Very High

In terms of youth's positive affection toward the Catholic Church, the data points out that as a whole, the students' positive affection toward the Catholic Church 4.50 which can mean that they strongly agree with the questions raised in the study. Specifically, the youth strongly agree that they feel the Catholic Church is important in making young people closer to God (4.56), the Catholic Church is enjoyable 
(4.43), belonging to the Catholic Church makes me proud (4.48), makes them feel good (4.51), makes them happy (4.52), and satisfied (4.50).

The students' positive affective attitude toward the Catholic Church is confirmed by their negative affective attitude toward the Catholic Church. Based on the data presented, it appears that as a whole, the negative affective attitude of youth toward the Catholic Church gained a composite mean of 1.39 which means that students strongly disagree with the questions raised. Particularly the youth strongly disagree that the Catholic Church makes them angry (1.35), does not make them happy (1.40), makes them upset (1.41), does not make them proud (1.39), does not make them free person (1.41) and they strongly disagree that the Catholic Church is an additional burden to them (1.38).

In short, the negative affective attitude of students toward the Catholic church confirms their positive affective attitude toward the Catholic Church. In other words, the youth have a very high positive feeling toward the Catholic Church.

Problem 3: What is the behavioral intention of the Ilocanos' Catholic youth to help the social action of the Church in terms of:
a. Positive intention
b. Negative intention

Table 03. Catholic youth's behavioral intention to help social action of the church

\begin{tabular}{|l|l|l|}
\hline Positive behavioral component & Mean & DR \\
\hline $\begin{array}{l}\text { 1. I will contribute any amount in the future to help the social action of } \\
\text { the Church. }\end{array}$ & 4.26 & SA \\
\hline 2. I will participate in the effort of the Church to elevate human poverty. & 4.23 & SA \\
\hline 3. I will help the Church in its effort to fight against injustices. & 4.30 & SA \\
\hline 4. I am inclined to follow the Church to help the poor. & 4.22 & SA \\
\hline 5. I feel drawn to do acts that benefit others in Church. & 4.21 & SA \\
\hline Composite Mean & 4.24 & SA \\
\hline Negative Component & Mean & DR \\
\hline 1. I will not contribute anything to Church. & 1.64 & D \\
\hline $\begin{array}{l}\text { 2. I will not participate in the effort of the Church to help its programs in } \\
\text { social action. }\end{array}$ & 1.66 & SDA \\
\hline 3. I will not participate in its effort to fight against injustices. & 1.67 & SDA \\
\hline 4. I am not inclined to follow the Church to help the poor. & 1.68 & SDA \\
\hline $\begin{array}{l}\text { 5. Even if I am promised of eternal salvation to help the poor, I am not } \\
\text { inclined to do it. }\end{array}$ & 1.65 & SDA \\
\hline Composite Mean & 1.66 & SDA \\
\hline
\end{tabular}

Legend:
4.21-5.00
Strongly agree
Agree
$3.41-4.20$
Somewhat agree
$2.61-3.40$
Disagree
$1.81-2.60$
Strongly disagree

Very High
High
Moderate
Low/High
Very Low/Very High

Concerning the behavioral intention of the youth to help the Social Action of the Catholic Church, in terms of positive behavioral intention, the data manifest that as a whole, the youth reaches a composite mean of 4.24 which means that the youth strongly agree to help the Social Action of the Catholic Church. Even when taking the questions singly, the date shows that the youth strongly agree that they will contribute any amount in the future to help the social action of the Church (4.26), participate in the effort of the Church to elevate human poverty (4.23), help the Church in its effort to fight against 
injustices (4.30), follow the Church to help the poor (4.22), and do acts that benefit others in Church (4.21).

Their negative behavioral intention seems to support their positive behavioral intention as indicated by data. The data indicates that as a whole the youth have 1.66 composite mean which means that they strongly disagree with the concerns raised in the survey. Specifically, the youth strongly disagree that they will not contribute anything to Church (1.64), will not participate in the effort of the Church to help its programs in social action (1.66), will not participate in its effort to fight against injustices (1.67), will not follow the Church to help the poor (1.68), and they strongly agree that even if they are promised of eternal salvation to help the poor, they will not be inclined to do it (1.65).

Overall, the analysis of data indicates that the students will help the Catholic Church in their social action programs in the future.

Problem 4: Is there a relationship between cognitive and affective attitude toward the Catholic Church and behavioral intention to help the social action of the Church?

Table 04. Relationship between cognitive, affective attitudes toward behavioral intention

\begin{tabular}{|c|c|c|c|c|c|c|c|}
\hline \multicolumn{2}{|c|}{ Particulars } & \multirow{2}{*}{\begin{tabular}{|l}
$\begin{array}{l}\text { Oognitive } \\
\text { Positive }\end{array}$ \\
$\mathrm{n} 1$
\end{tabular}} & \multirow{2}{*}{\begin{tabular}{|l|}
$\begin{array}{l}\text { Cognitive } \\
\text { Negative }\end{array}$ \\
$-.408^{* *}$ \\
\end{tabular}} & \multirow{2}{*}{\begin{tabular}{|l} 
Affective \\
Positive
\end{tabular}} & \multirow{2}{*}{\begin{tabular}{|l} 
Affective \\
Negative
\end{tabular}} & \multirow{2}{*}{\begin{tabular}{|l}
$\begin{array}{l}\text { Behavioral } \\
\text { Positive }\end{array}$ \\
$258^{* *}$ \\
\end{tabular}} & \multirow{2}{*}{$\begin{array}{l}\text { Behavioral } \\
\text { Negative } \\
-.506^{* *}\end{array}$} \\
\hline \multirow{3}{*}{$\begin{array}{l}\text { Cognitive } \\
\text { Positive }\end{array}$} & Pearson Correlation & & & & & & \\
\hline & Sig. (2-tailed) & & .000 & .000 & .000 & .000 & .000 \\
\hline & $\mathrm{N}$ & 323 & 323 & 323 & 323 & 323 & 323 \\
\hline \multirow{3}{*}{$\begin{array}{l}\text { Cognitive } \\
\text { Negative }\end{array}$} & Pearson Correlation & $1-.408^{* *}$ & 1 & $-.239^{* *}$ & $.580^{* *}$ & $-.217^{* *}$ & $.373^{* *}$ \\
\hline & Sig. (2-tailed) & .000 & & .000 & .000 & .000 & .000 \\
\hline & $\mathrm{N}$ & 323 & 323 & 323 & 323 & 323 & 323 \\
\hline \multirow{3}{*}{$\begin{array}{l}\text { Affective } \\
\text { Positive }\end{array}$} & Pearson Correlation & $355^{* *}$ & $-.239^{* *}$ & 1 & $-.306^{* *}$ & $.577^{* *}$ & $-.381^{* *}$ \\
\hline & Sig. (2-tailed) & .000 & .000 & & .000 & .000 & .000 \\
\hline & $\mathrm{N}$ & 323 & 323 & 323 & 323 & 323 & 323 \\
\hline \multirow{3}{*}{$\begin{array}{l}\text { Affective } \\
\text { Negative }\end{array}$} & Pearson Correlation & $1-.267^{* *}$ & $.580^{* *}$ & $-.306^{* *}$ & 1 & $-.291^{* *}$ & $449^{* *}$ \\
\hline & Sig. (2-tailed) & .000 & .000 & .000 & & .000 & .000 \\
\hline & $\mathrm{N}$ & 323 & 323 & 323 & 323 & 323 & 323 \\
\hline \multirow{3}{*}{$\begin{array}{l}\text { Behavioral } \\
\text { Positive }\end{array}$} & Pearson Correlation & $258^{* *}$ & $-.217^{* *}$ & $.577^{* *}$ & $-.291^{* *}$ & 1 & $-.369^{* *}$ \\
\hline & Sig. (2-tailed) & .000 & .000 & .000 & .000 & & .000 \\
\hline & $\mathrm{N}$ & 323 & 323 & 323 & 323 & 323 & 323 \\
\hline \multirow{3}{*}{$\begin{array}{l}\text { Behavioral } \\
\text { Negative }\end{array}$} & Pearson Correlation & $-.506^{* *}$ & $.373^{* *}$ & $-.381^{* *}$ & $449^{* *}$ & $-.369^{* *}$ & 1 \\
\hline & Sig. (2-tailed) & .000 & .000 & .000 & .000 & .000 & \\
\hline & $\mathrm{N}$ & 323 & 323 & 323 & 323 & 323 & 323 \\
\hline
\end{tabular}

${ }^{* *}$ Correlation is significant at the 0.01 level (2-tailed).

In terms of its correlation between cognitive and affective attitude and the behavioral intention of the youth to help the Social Action programs of the Catholic Church, the Pearson r correlation indicates that there is a significant correlation at 0.01 level (2-tailed). It means that the cognitive and affective attitude of the youth toward the Catholic Church has something to do with their behavioral intention to help the Church in the future.

\section{Discussion}

The empirical data and analysis indicate that in order to improve Church member's participation in the Social Action of the Church, it is necessary for the Catholic Church to focus more on improving the knowledge of the youth on the Catholic faith and provides activities or programs that improve their affection toward the Catholic Church.

Failing to improve their knowledge on the Catholic faith will mean that they do not have an idea about the Catholic Church and consequently it will affect their affective attitude or feeling toward the Catholic Church. A very high positive cognitive and affective attitude will lead to high involvement in the Church programs. 


\section{Conclusion}

The study was inspired by the theory Allport (1968) and Aljzen (1993) that attitude is a key predictor toward behavior and based on that theory the current concludes that there is a correlation between cognitive and affective attitude of the youth's behavioral intention to help the Catholic Church Social Action Programs in the future.

The study confirms earlier findings of the relationship between human attitude and human behavior. The finding of the study suggests that the Catholic Church should focus on the faith formation of the youth and social activities that can instill positive feelings toward the Catholic Church.

Given those observations, the study recognizes its limitations that the respondents were limited to the youth who are studying in the Catholic School. A wider study that includes out of school youth is necessary to get a comprehensive picture of the attitude of the Catholic youth toward the Catholic Church and their plan to help the Church in the future.

\section{References}

[1]. Abun, D. and Racoma, A. (2017). Environmental attitude and environmental behavior of catholic colleges' employees in Ilocos Sur, Philippines. Texila International Journal of Academic Research, 4 (1), 23-52. https://doi.org/10.21522/TIJAR.2014.04.01.Art003

[2]. Abun, D. Foronda, S. L. G. Agoot, F. Belandres, M. L. V. and Magallanez, Th. (2018). Measuring entrepreneurial attitude and entrepreneurial intention of ABM grade XII, Senior High School Students of Divine Word Colleges in Region I, Philippine. International Journal of Applied Research, 4 (4), 2018.

[3]. Abun, D. Magallanes, Th. Encarnacion, M. J. Alkalde, F. and Somera, K. A. (2019). Investigation of Cognitive and Affective Attitude of Students toward Environment and Their Environmental Behavioral Intention to Join Environmental Movement and Energy Conservation. The International Journal of Business and Management Technology, Vol. 3, Issue, 6, NovemberDecember 2019

[4]. Ajzen, I. (1985). From intention to actions. A theory of planned behavior. In: Kuhl, J. and Beckmann (Eds.). Action Control: From Cognition to Behavior, pp.11-39. Heidelberg: Springer. https://doi.org/10.1007/978-3-642-69746-3_2

[5]. Ajzen, I. (1987). Attitude, Trait and actions: dispositional prediction of behavior in personality and social psychology. In: Berkowitz, L. (Ed). Advances in Social Psychology, Vol. 20, pp.1-63. New York: Academic Press. https://doi.org/10.1016/S0065-2601(08)60411-6

[6]. Ajzen, I. and Madden, T. J. (1986). Prediction of goal directed behavior: attitudes, intentions, and perceived behavioral control. Journal of Experimental Psychology, 22, pp. 426-435.

https://doi.org/10.1016/0022-1031(86)90045-4

[7]. Ajzen, I. (1993). New Directions in Attitude Measurement. New York: Walter de Gruyter.

[8]. Ajzen, I. and Fishbein, M. (1977). Attitude - Behavior Relations: A Theoretical Analysis and Review of Empirical Research. Psychological Bulletin, 84, 888-918. https://doi.org/10.1037/0033-2909.84.5.888

[9]. Ajzen, I. and Fishbein, M. (1980). Understanding attitudes and predicting social behavior. New York: Prentice-Hall.

[10]. Ajzen, I. and Fishbein, M. (2000). Attitudes and the Attitude-Behavior relation: Reasoned and Automatic Processes. In Stroebe, W. and Hewstone, M. (Eds.). European Review of Social Psychology, Vol. 11. pp. 1-33. Chichester, UK: Wiley.

https://doi.org/10.1080/14792779943000116

[11]. Allport, G. W. (1954). The Historical Background of Modern Social Psychology. In Lindsay, G. (Ed.). Handbook of Social Psychology, Vol. 1. Pp. 3-56. Cambridge, MA: Addison-Wesley.

[12]. Allport, G. (1935). "Attitudes," in a Handbook of Social Psychology, ed. C. Murchison. Worcester, MA: Clark University Press. pp. 789-844.

[13]. Allport, G. W. (1968). The Historical background of Modern Social Psychology. In G. Lindsay and E. Aronson (Eds.). Handbook of Social Psychology. Reading, MA: Addison-Wesley.

[14]. Amstrong, W. R. (1996). The Relationship between Culture and Perception of Ethical Problems in International Marketing. Journal of Business Ethics, 15 (11), 1199-1208. 
https://doi.org/10.1080/14792779943000116

[15]. Ariola, M. M. (2006). Principles and Methods of Research. Manila: National Bookstore.

[16]. Baldelomar, C. (2010). Vatican II, 101: Social Justice is Part of Catholic Identity. Sojourners. Retrieved from https://sojo.net/articles/vatican

[17]. Banaji, M. R. and Heiphetz, L. (2010). Attitudes. In Fiske, S. T. Gilbert, D. T. and Lindzey, G. (Eds). Handbook of Social Psychology (5th ed.), Vol. 1. Pp. 353-393. Hoboken, NJ: John Wiley \& Sons.

[18]. Bem, D. J. (1970). Beliefs, Attitudes and Human Affairs. Belmont, CA: Brooks/Cole.

[19]. Blainey, G. (2011). A Short History of Christianity; New York: Penguin Viking

[20]. Brooke, J. H. and Numbers, R. L. (2011). Science and religion around the world. New York: Oxford University Press. p. 71

[21]. Brown, A. (1995). Organizational Culture. London: Pitman Publishing.

[22]. CBCP: Episcopal Commission for the Youth and Catholic Educational Association of the Philippines (2013). National Catholic Youth Survey. Retrieved from www.cbcp-ecy.ph

[23]. CBCP: Episcopal Commission for the Youth and Catholic Educational Association of the Philippines (2014). The Filipino Catholic Youth in the Visayas. Retrieved from

https://www.researchgate.net.

[24]. Cherry, K. (2019). Attitudes and Behaviors in Psychology. Very Well Mind. Retrieved from https://www.verywellmind.com.

[25]. Corey, S. M. (1937). Professed attitudes and actual behavior. Journal of Educational Psychology, 28(4), 271-280. https://doi.org/10.1037/h0056871

[26]. Dean, L. R. (1958). Interaction reported and observed the case of one local union. Human Organization, 17, 36-44. https://doi.org/10.17730/humo.17.3.2320447q44475876

[27]. DeFleur, M. L. and Westie, F. R. (1958). Verbal Attitude and Overt Acts: An Experiment on the Salience of Attitude. American Sociological Review, 23(6), 667.

https://doi.org/10.2307/2089055

[28]. Deutscher, I. (1968). Looking Backward: Case Study on the Progress of methodology in sociological research. American Sociologist, 4, 35-41.

[29]. Donald, M. (2002). A Mind So Rare: The Evolution of Human Consciousness. New York: W.W. Norton \& Company, Inc.

[30]. Duncan, B. (2006). Why the Church Stresses Social Justice So Strongly Today. Proclaiming Justice. Retrieved from https://www.cssr.org.au.

[31]. Edwards, A. L. (1957). The technique of Attitude Scale Construction. New York: AppletonCentury- Crofts. https://doi.org/10.1037/14423-000

[32]. Episcopal Commission on Youth (2003). National Filipino Catholic Survey 2002. Retrieved from www.cbcp-ecy.ph.

[33]. Fishbein, M. and Ajzen, I. (1975). Beliefs, Attitude, Intention, and Behavior: An Introduction to theory and research. Reading, MA: Addison-Wesley.

[34]. Fitzsimmons, J. R. and Douglas, E. J. (2005). "Entrepreneurial attitudes and entrepreneurial intentions: a cross-cultural study of potential entrepreneurs in India, China, Thailand and Australia", Babson-Kauffman Entrepreneurial Research Conference, Wellesley, MA.

[35]. Freeman, L. C. and Ataoev, T. (1960). The invalidity of indirect and direct measures of attitude toward cheating. Journal of Personality, 28, 443-447.

https://doi.org/10.1111/j.1467-6494.1960.tb01631.x

[36]. Gönenç, L. (2002). Prospects for Constitutionalism in Post-Communist Countries. The Netherlands: Kluwer Law International. p. 218.

[37]. Goyette, J. Latkovic, M. S. and Myers, R. S. (2004). St. Thomas Aquinas and the Natural Law Tradition: Contemporary Perspectives. Washington D.C.: The Catholic University of America Press.

[38]. Gushee, D. P. (2014). In the Fray: Contesting Christian Public Ethics, 1994-2013. Eugene, Oregon: Cascade Books. p. 109.

[39]. Hilgard, E. R. (1980). The trilogy of mind: Cognition, affection, and conation. Journal of the History of the Behavioral Sciences, 16, 107-117.

https://doi.org/10.1002/1520-6696(198004)16:2<107::AID-JHBS2300160202>3.0.CO;2-Y

[40]. Hittinger, R. (2013). Quinquagesima Ante: Reflections on Pacem in Terris Fifty Years Later. Pontifical Academy of Social Sciences, Acta 18, 2013 Retrieved from www.pass.va/content/dam/scienzesociali/pdf/acta18/acta18-hittinger.pdf. 
[41]. Keller, T. (2008). The reason for god- belief in an age of skepticism. New York: Penguin Books. p. 249.

[42]. Kim, D. and Kaul, S. (2015). Imagining Human Rights. Berlin, Germany: de Gruyter. pp. 13-17.

[43]. Lawler, M. S. (2006). William James' Psychological Pragmatism: Habit, Belief and Purposive Human Behavior. Cambridge Journal of Economics, 30 (3), 321-345.

https://doi.org/10.1093/cje/bei062

[44]. Lecky, W. E. H. (1920). History of European Morals from Augustus to Charlemagne. 2. London, England: Longman's, Green, and Co.

[45]. Paul VI. J. (1967). Populorum Progressio: Encyclical of Pope Paul VI on the Development of Peoples. Retrieved from http://w2.vatican.va/content/paulvi/en/encyclicals/documents/hf_p-vi_enc_26031967_populorum.html.

[46]. Richardson, D. (n.d). Understanding Attitude in Social Psychology. Dummies. Retrieved from https://www.dummies.com/education/psychology/understanding-attitudes-in-socialpsychology/.

[47]. Ridley, M. (2003). A Review of Nature via Nurture: Genes, Experience, and What Makes Us Human. New York: HarperCollins.

[48]. Rosenberg, M. J. and Hovland, C. I. (1960). Cognitive, affective and behavioral components of attitudes. In Hovland, C. I. and Rosenberg, M.J. (Eds). Attitude Organization and Change. pp. 114. New haven, CT: Yale University Press.

[49]. Rymarz, R. and Graham, J. (2006). Going to church attendance amongst Australians Core Catholic Youth. Journal of Beliefs \& Values, 26 (1). https://doi.org/10.1080/13617670500047657

[50]. Sarmiento, P. (2016). Attitude and practices of Filipino catholic youth toward mary, the mother of god: implications to the religious education in the Philippines. De La Salle University NCCRE, $1(1)$.

[51]. Sadowski, D. (2017). Encyclical Influence on Church's Social Action Work Continues. Retrieved from https://www.ncronline.org

[52]. Sorondo, M. S. (2013). "The Magnitude of Walking in the Truth". Pontifical Academy of Social Sciences, Acta 18, 2013 www.pass.va/content/dam/scienzesociali/pdf.

[53]. Swanbrow, D. (2005). Attitudes of Roman Catholics Continue to Change. University of Michigan: The University Records Online. Retrieved from http://www.ur.umich.edu.

[54]. Thomas, W. I. and Znaniecki, F. (1918). The Polish Peasant in Europe and America (vol. 1). Boston: Badger.

[55]. United States Conference of Catholic Bishops (1998). Sharing Catholic Social Teaching: Challenges and Directions. Washington, DC: USCCB.

[56]. Watson, J. B. (1925). Behaviorism. New York: Norton.

[57]. Wicker, A. W. and Pomazal, R. J. (1971). The relationship between attitudes and behavior as a function of specificity of attitude object and the presence of a significant person during assessment conditions. Representative Research in Social Psychology, 2(2), 26-31.

[58]. Wicker, A. W. (1969). Attitudes versus actions: The relationship of verbal and overt behavioral responses to attitude objects. Journal of Social Issues, 25, 41-78.

https://doi.org/10.1111/j.1540-4560.1969.tb00619.x 


\section{HOW TO CITE THIS ARTICLE?}

\section{MLA}

Abun et al. "Measuring Ilocano's catholic youth's attitude toward the catholic church and their behavioural intention to help the social action of the catholic church in the Philippines context". International Journal of Business, Management and Social Research 08(02) (2020): 473-488.

\section{APA}

Abun, D. Magallanes, T. Barroga, J. R. Encarnacion, M. J. and Foronda, S. L. (2020). Measuring Ilocano's catholic youth's attitude toward the catholic church and their behavioural intention to help the social action of the catholic church in the Philippines context. International Journal of Business, Management and Social Research, 08(02), 473-488.

\section{Chicago}

Abun, D. Magallanes, T. Barroga, J. R. Encarnacion, M. J. and Foronda, S. L. "Measuring Ilocano's catholic youth's attitude toward the catholic church and their behavioural intention to help the social action of the catholic church in the Philippines context". International Journal of Business, Management and Social Research, 08(02) (2020): 473-488.

\section{Harvard}

Abun, D. Magallanes, T. Barroga, J. R. Encarnacion, M. J. and Foronda, S. L. 2020. Measuring Ilocano's catholic youth's attitude toward the catholic church and their behavioural intention to help the social action of the catholic church in the Philippines context. International Journal of Business, Management and Social Research, 08(02), pp. 473-488.

\section{Vancouver}

Abun D, Magallanes T, Barroga JR, Encarnacion MJ and Foronda SL (2020). Measuring Ilocano's catholic youth's attitude toward the catholic church and their behavioural intention to help the social action of the catholic church in the Philippines context. International Journal of Business, Management and Social Research. 2020 April. 08(02), 473-488. 